
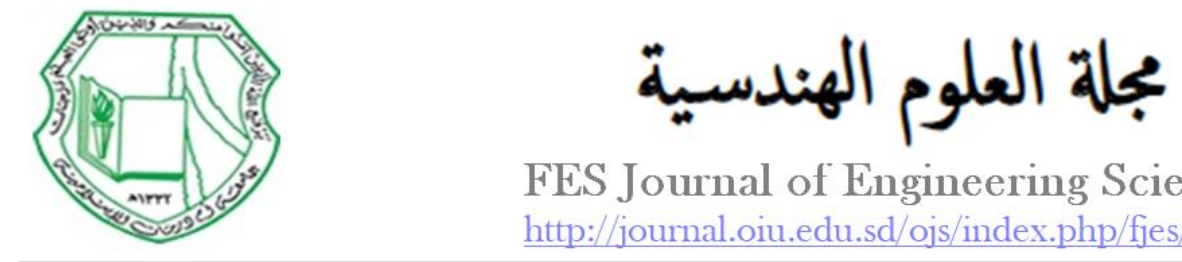

\title{
Price Adjustments in the Sudanese Construction Industry for Public-funded projects
}

\author{
Yousif Hummaida Ahmed ${ }^{1, *}$, Nasrddin Khalil Sharafeldinn', Eman Norallah Mohamed Taber ${ }^{3}$ \\ 1 Department Of Civil Engineering, Faculty of Engineering, University of Khartoum, Sudan \\ 2 Department Of Architecture Engineering, Faculty of Engineering, University of Khartoum, Sudan \\ 3 Structural Engineering Department of Sudan University of Science and Technology, Sudan \\ * Corresponding author: Yasir M. H. Badawi (e-mail: y.hummaida@uofk.edu).
}

Article history: Received 14 March 2020, Received in revised form 4 November 2020, Accepted 11 November 2020

\begin{abstract}
In recent years Sudan suffers from deterioration in the economy. There are three financial legislations issued from the Government of Sudan between Nov 2016 and Oct 2018. These legislations have led to increase in prices of all goods and materials especially construction materials that lead many contracting companies to submit claims demanding for adjustment of prices. This paper documents effort by the Government of Sudan (GoS) to address price adjustments for public-funded projects affected by the mentioned legislations. It also validates some data submitted by the contractors to examine the adjustment through a technical committee established for that purpose. Furthermore, the GoS has introduced a program to build the capacity of all involved parties in the construction industry to calculate price adjustments. This paper compares some data submitted by some contractors for three projects in east Sudan (Qadarif), West Sudan (Zalingei) and central Sudan (Khartoum) that have been approved by consultants with prices of materials obtained from an independent third party the in Khartoum. The results of the comparison are found that some increase in material follows the prices of the (USD) dollar as reinforcement and some local material increase in price due to other reasons like fees of transportation. Also, when comparing prices in different states in Sudan, there are differences in some material depending on the distance from Khartoum and the availability of the materials in the states like local materials as aggregates and red bricks.
\end{abstract}

Keywords: claims, financial legislations, Price adjustment technical committee, validation.

\section{INTRODUCTION}

Since the beginning of the crisis of the global economic collapse in 2007, the entire world has affected in the various fields. Global growth witnessed a sharp slowdown in 2008 and was accompanied by a significant increase in inflation rates under the influence of the commodity price boom. Many developed economies are either in a situation close to the recession or on the verge of entering it, and this has had negative repercussions that have included all economic sectors, including the construction industry.

Generally, in the construction industry, the contractor works in an environment of risk and uncertainty caused by economic factors such as changes in costs of materials, labour and equipment. Workers in the construction field find that estimating, bidding and financing the construction projects are challenges due to the lack of fixed prices of materials. A clause in the contract must be made for adjusting prices, especially in long-period projects, and many of the implementing companies demanded a price adjustment, hence the importance of the price adjustment clause in the contract [1].

The definition of price adjustment is the provision in a cost estimate for changing in the cost of equipment, material, labour, etc., due to continuing price changes over time[2].

The purpose of price adjustment is to protect the parties (Contractor, Client and consultant) 
against unexpected price escalations. A price adjustment may also make savings to the client due to the reductions in prices[3].

Implementing price adjustment provisions requires an extensive verification process and skillset in contract management. It is important to ensure that the party who will certify price adjustment on behalf of the Client has strong qualifications and specific experience in dealing with price adjustment issues[3].

Sudan is one of the countries that suffer from a significant deterioration in the economy, especially after the secession of South Sudan in 2010. It lost petroleum revenue that represents $80 \%$ of the foreign exchange resources. This led to the deterioration of local currency rate (pound) against foreign currencies. The financial legislations were made to address the situation, as follows:

i. The Legislation of lifting fuel subsidies as well as lowering the exchange rate for the Sudanese pounds against foreign currency in 23.Sep.2013.

ii. The legislation of lifting fuel subsidies issued in Nov. 2016 to Dec 2017; when the liter of Gasoline price increased from 3.11 to 4.11pounds and Diesel from 4.67 to 6.17 pound.

iii. The legislation is the change of official exchange rate \& custom excise issued on 1.Jan. 2018 - Sep 2018, the USD official rate increased from 6.8 to 18 pound and calculating of customs are based on the new USD rate.

iv. The legislation is known as Market Mechanism issued on 5 Oct. 2018; the official rate of USD increased to 47 pounds, without affecting the custom excise rate of 18 SDG. It also posed restriction in importing several luxury goods. This increase in the price of the USD withdrew from the customs dollar, which in turn led to higher prices for many goods and services, especially in the area of construction, fees, and relocation and transportation categories.

These legislations led to the raising of all price goods, including construction materials, thus have impact on all projects, especially ongoing development projects funded by the Ministry of Finance and Economical Planning (MoF). The recent economic measures have had a clear impact on the contracting sector and this was represented by the dramatic rise in the prices of building materials like prices of reinforcement, cement and so on as illustrated in Fig. 1 \& 2 . Furthermore, there was a crisis of lacking cash flow in the banks, scarcity of cash in banks between Feb.2018 up to Oct.2019 and stopping the import was reflected on the construction market.

Working on adjusting prices of construction projects according to the current economy is pivotal for national contracting companies to continue businesses. This is important to keep workers, unskilled labour and even specialized engineers employed. Immediate remedies should be taken, including taking strictly policies to regulate the sector and its financing and to provide a competitive and investment environment to attract foreign capitals.

This paper documents the efforts made by the GoS to address price adjustments in the public-funded projects by the (MoF). It also validates the calculation of parameters for some projects that are not supported by initial contract prices \& current prices evidence - based documents as required. Furthermore, it addresses the issue of validating prices for some material (namely, cement, steel rebar, coarse and fine aggregate and red bricks) in claims approval by MoF-GoS committee. This is carried out by examining prices of certain building material, such as (cement, coarse aggregate, fine aggregate and red fired brick) for three projects. These projects are located in central Sudan (Khartoum), Qadarif (Eastern Sudan) and Zalingei (Western Sudan).

\section{LITERATURE REVIEW}

Price adjustment has been affecting the construction industry during the previous year's causing many problems and many developers to rethink projects. Price adjustment produces delays in construction projects, reduced scope projects or projects being cancelled[4]. Measuring or managing escalation on construction projects, it is first important to understand the driving forces behind it. This is especially critical in the current situation, where price fluctuations have been so volatile that it has been difficult to predict or estimate what bid prices might be. The most important factor in the construction industry is that construction must be viewed as a commodity 
in itself, not a collection of commodities. Furthermore, the selling price of a project is not the result of the sum of its inputs plus a profit, except in the very rare cases where all work, including sub-contracts, is procured through a cost-plus contract[5].

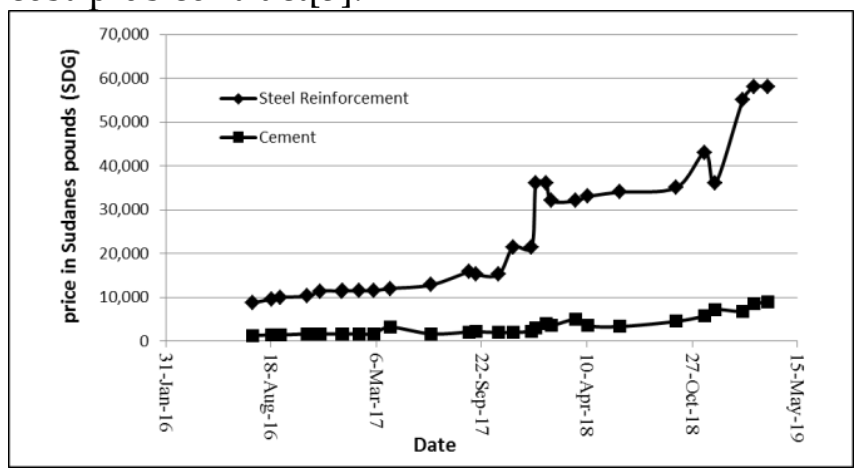

Fig. 1: Prices of reinforcement and Cement [Courtesy of: N.Khalil member of MTC]

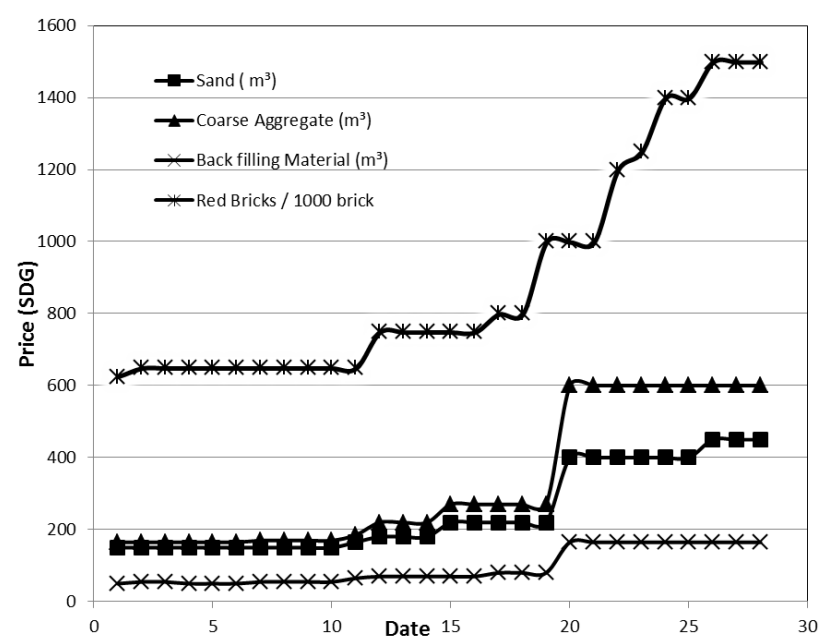

Fig 2: Prices of Redbrick (1000 unit), Coarse aggregate $\left(\mathrm{m}^{3}\right)$, Sand $\left(\mathrm{m}^{3}\right)$ and backfilling material $\left(\mathrm{m}^{3}\right)$.[Courtesy of: N.Khalil member of MTC]

Price adjustments provisions include formulae designed to address problems, using of the formulae allow contractors to offer more realistic prices at the time of bidding. Despite concerns that they may lead to budget uncertainties, price adjustment formulae will estimate the actual cost implications that will be encountered. They use indices that can be applied for cost prediction[3]

All conditions in construction management try to be fair and save the rights of all parties and give them wright to raise claim to any extension of the Time for Completion and/or any additional payment, connection with the Contract or law [6].

\section{DATA COLLECTION \& PRICE ADJUSTMENT} METHODS

\section{A. Data Collection}

Data are collected from the MoF committee meeting minutes and through personal communication of the committee members to produce this paper, Following the legislation issued by the GoS to reform economic policies and based on the joint meeting with the Minister of Transport, Roads and Bridges and Resolution No. 49 of 2017 and the decision of the Under-Secretary of Economic Planning Resolution No. 6 of 2018 it was decided to form committee to address the price adjustment for development projects. After forming the first committee to address the price adjustment, another committee named is Recommendation Follow up Committee (RFC) was formed having many objectives and decisions as documented from the minutes of meetings and interim reports ${ }^{1}$.

- The objectives of this committee are:

1-Studying the price adjustment that occurred in the preceding period that affected companies implementing development projects and recommending ways to address price adjustment for projects financed by guarantees and treasury.

2- Preparing proposals for how to pay the price adjustment and financing the remaining projects affected by that increase.

- The objectives and specializations of the committee are as follows

1- Adopting a general classification for development projects affected by the price adjustment that occurred in the previous period, and categorizing them in groups.

2- Adopting an objective criterion for calculating the price adjustment for these projects.

3- Determining the period for applying price adjustment by the adopted objective criteria.

4- Making a decision on how to apply to implement conditions collectively or for each

${ }^{1}$ The reports and minutes of meeting are unpublished and found in MoF building. 
project by mutual contractual obligations for both parties.

5- Determining the type of projects that the amendment applies to in terms of its financing method (guarantees from Banks and treasuries).

6- Preparing proposals for how to pay the price adjustments and finance the remaining projects affected by these financial legislations.

Then a Miniature Technical Committee (MTC) was formed from the RFC in Resolution No. 28 representative of two accountants from $\mathrm{MoF}$ and Engineers experts of the RFC. Periodical meetings of the MTC have taken place in the offices of the $\mathrm{MoF}$ to receive claims from contractors for a price adjustment and to study each project according to its details and calculate the percentage of price adjustment and its approval to present it to the MoF. The meetings by the MTC have been convened between Aug. 2018 and Feb.2020. The meetings are scheduled to be held weekly, but unfortunately they are not held as planned for many reasons, like political turmoil events and the budget preparations.

The MTC has decided that the implementation of the 2016 Committee decisions with regard to the economic legislation issued in November 2016 will be applied to the works accomplished during 2017 of the project contracts affected by those decisions. Also, the MTC scope will be applied from $1 / 1 / 2018$ and the contracts projects that preceded 2016, which were affected by the economic legislations in September 2013, should be treated as individual cases on the guidance of the outputs of this committee.

The MTC examined the international experiences in effect in this matter, as there are two methods used to deal with price adjustments:

- Documentary proof

- Adjustment formula

After careful study, the MTC has decided that Documentary proof method is the easiest to apply and most accurate if the project is well documented. However, the committee recommended using the latter method for many reasons as:

- It handles projects that have incomplete documentation and relies on secondary information such as national or official prices indices.

- The method is flexible and easy to apply for each individual project.

- It is internationally accredited as well as its references in Purchase and Contract Documents issued by the MoF and Economic Planning

The formula for adjusting prices takes the following form

P.A. $=a+b \frac{L_{1}}{L_{s}}+c \frac{M_{1}}{M o}+d \frac{M_{i s}}{M i s} \ldots$

Where

P.A $\equiv$ escalation factor for the work carried out in the period " $n$ ".

$\mathrm{a} \equiv$ is a constant accounting for Non-Adjustable Portion of the Price Adjustment Factor (overhead \& profit) stated to be equal 0.15.

$b \equiv$ coefficients or weights of the order of $0 . x x$ (i.e., fractions having two significant digits) for labour of the total contract price without value added tax (VAT).

$c \equiv$ coefficients or weights of materials.

$\mathrm{d} \equiv$ coefficients or weights of others.

$L_{1} \equiv$ wages of labour at the current date.

$L_{\varpi} \equiv$ wages of labour at the submitted date of bid.

$M_{1} \equiv$ price of materials at the current date

$M_{0} \equiv$ price of materials at the submitted date of bid.

$M i s_{1} \equiv$ price of others like equipment at the current date.

Mis $\equiv$ price of others at the submitted date of bid.

\section{B. Assigning and validation some submitted data by the claimant}

The following general requirements are set by the MTC to be established before examining any claim for price adjustment:

- Submitting the contractor's claim

- Looking at the basic information of the project (project name, location, baseline price data, contract.....).

- Date and amount of payment submitted by contractors \& approved by the consultant.

- Calculating the quantity and weights of materials and not the values of bill of quantiles 
items in each project in relation to the total cost of the project.

- calculate Indices of all materials based on the basic prices and the current bid prices.

- Calculating the labour percentage of the project after fixing the profit percentage and the overhead (15\%).

- Apply in the formula to calculate the adjustment rate.

The MTC organized a workshop on .........and invited all stakeholders (contractors and consultants) to train them for using the formula for calculating price adjustments, as well as provision of basic data for projects under claim. Despite these efforts, the MTC has received many claims that were not prepared by the recommended methods, thus highlighting the lack of experience in the construction sector to deal with price adjustment. Several claims were returned to the contractor and consultants in order to adhere to the requirement. Party independent prices and examine three projects covering different localities from the Sudan.

\section{The methodology of validation projects}

This validation section is an attempt by the authors to check validity for some projects approved by the MTC, but as the MTC has no independent prices. The authors obtained data from three projects (approved by the MTC) from three regions located at (Central, East, and West) of Sudan, comparing the prices in these projects with material prices obtained from an independent third party from Khartoum, viz comparing basic prices with new prices for affected payment by financial legislations, and noted any underlying causes.

- Comparing basic and current prices with that come from the third party as illustrated in Tables I.

- Comparing basic and current prices for the East \& West projects with Khartoum projects as illustrated in Table I.

Example for projects from different states in Sudan

1-The basic information of the projects (project name, location, baseline price data, contract.....) are checked.

2- Sorting the date and amount of payment submitted by contractors \& approved by the consultant.
3-The basic material of project and its prices illustrated in Table I.

Correlation between the current price and basic price

Inflation factors for cost estimates formula [13]

$$
p_{N}=p_{\circ}[1+i]^{n}
$$

Where

$p_{N} \equiv$ Total Inflated Estimated Cost

$p_{\circ} \equiv$ Base estimated Cost

i $\equiv$ Inflation Rate

$\mathrm{n} \equiv$ Difference between Base Year and Selected Year or Base month and Selected month, e.g. $2010-2005=5$ years, therefore $n=5$.

The inflation rate (i) during a certain period (n) for any material can be calculated of $p_{N}$ and p. are known.

$$
i=\left[\frac{p_{N}}{p_{\circ}}\right]^{\frac{1}{n}}-1
$$

Calculating indices for prices projects for the base and new prices and indices of the dollar as illustrated in tables II.

TABLE II: INFLATION FACTOR FOR KHARTOUM PROJECT

\begin{tabular}{c|c|c|c}
\hline \hline Material & $\boldsymbol{p}_{\boldsymbol{N}}$ & $\boldsymbol{p}$ & \\
$7 / 5 / 2018$ & $18 / 7 / 2017$ & $\boldsymbol{i}$ \\
\hline Cement & 3,600 & 2,150 & 0.05 \\
\hline Reinforcement & 28,500 & 14,000 & 0.07 \\
\hline Red brick & 1050 & 750 & 0.03 \\
\hline $\begin{array}{c}\text { USD /dollar } \\
\text { unofficial rate }\end{array}$ & 37 & 18.85 & 0.07 \\
\hline \hline
\end{tabular}

\section{RESULTS AND DISCUSSION}

From reviewing the efforts and minutes of meeting made by the MTC in MoF it is found many development projects funded by $\mathrm{MoF}$ do not include list of tables for materials, labour prices at the bidding date. Therefore, it is recommended that theses tables of prices should be mandatory and annexed to bill of quantities to indicate the indices to simplify adjustment in future if any unexpected changes happen and reduce the delay and total cost of project. 
TABLE I: MATERIAL FOR THE CLAIMANT PROJECTS FROM KHARTOUM, EAST AND WEST OF SUDAN

\begin{tabular}{|c|c|c|c|c|c|c|c|c|}
\hline Material & Unit & $\begin{array}{l}\text { Quantity in } \\
\text { project }\end{array}$ & $\begin{array}{l}\text { Basic Contract } \\
\text { price }(\mathrm{BCP}) \\
\text { Khartoum } \\
\text { 18/Jun./2017 }\end{array}$ & $\begin{array}{l}\text { Current Contract } \\
\text { price }(\mathrm{CCP}) \mathrm{KH} \text {. } \\
\text { 7/May./2018 }\end{array}$ & $\begin{array}{l}\text { Basic } \\
\text { Validation } \\
\text { price (BVP) } \\
\text { KH. 8/Jun.17 }\end{array}$ & $\begin{array}{l}\text { Current } \\
\text { Validation } \\
\text { price (CVP) } \\
\text { KH. } \\
\text { 7/May.18 }\end{array}$ & $\frac{B, C \cdot P}{B, V_{n} P}$ & $\frac{C_{n} C_{x} P}{C_{n} V_{n} P}$ \\
\hline Cement & ton & 296 & 2,150 & 3600 & 1,650 & 2,900 & 1.30 & 1.24 \\
\hline Reinforcement & ton & 79 & 14,000 & 28,500 & 12,800 & 32,000 & 1.09 & 0.90 \\
\hline Coarse aggregates & $\mathrm{M}^{3}$ & 546 & 200 & 260 & 185 & 300 & 1.08 & 0.87 \\
\hline Sand & $\mathrm{M}^{3}$ & 915 & 135 & 180 & 165 & 200 & 0.82 & 0.9 \\
\hline Red bricks & 1000 & 452 & 750 & 1,050 & 650 & 1,000 & 1.15 & 1.05 \\
\hline Material & Unit & Q.in. P & $\begin{array}{l}\text { (BCP)-East } \\
\text { Nov/2017 }\end{array}$ & $\begin{array}{l}\text { (CCP)-East } \\
\text { Jan /2018 }\end{array}$ & $\begin{array}{l}\text { (BVP)-KH. } \\
\text { Nov/2017 }\end{array}$ & $\begin{array}{l}\text { (CVP)KH. } \\
\text { Jan/2018 } \\
\end{array}$ & $\frac{B, C . P}{B . V P}$ & $\frac{C \cdot C P}{C_{W} P}$ \\
\hline Cement & ton & 58 & 2,750 & 3,100 & 2,000 & 4,000 & 1.40 & 0.78 \\
\hline Reinforcement & ton & 9 & 16,500 & 17,500 & 21,500 & 36,000 & 0.76 & 0.49 \\
\hline Coarse aggregates & $\mathrm{M}^{3}$ & 95 & 205 & 420 & 270 & 270 & 0.76 & 1.56 \\
\hline Sand & $\mathrm{M}^{3}$ & 159 & 100 & 210 & 220 & 220 & 0.45 & 0.95 \\
\hline Red bricks & 1000 & 146 & 550 & 1,050 & 750 & 800 & 0.73 & 1.31 \\
\hline Material & Unit & Q.in. P & $\begin{array}{l}\text { (BCP)-west } \\
\text { Nov/2017 }\end{array}$ & $\begin{array}{l}\text { (CCP)-west } \\
\text { Feb/2018 } \\
\end{array}$ & $\begin{array}{l}\text { (BVP)-KH } \\
\text { Nov/2017 } \\
\end{array}$ & $\begin{array}{l}\text { (CVP)-Kh } \\
\text { Feb/2018 } \\
\end{array}$ & $\frac{B \cdot C \cdot P}{B \cdot V P}$ & $\frac{C \cdot C \cdot P}{C \cdot P}$ \\
\hline Cement & ton & 262 & 1,750 & 3,500 & 2,000 & 3,550 & 0.88 & 0.99 \\
\hline Reinforcement & ton & 79 & 18,000 & 26,500 & 21,000 & 32,000 & 0.88 & 0.83 \\
\hline Coarse aggregates & $\mathrm{M}^{3}$ & 545 & 200 & 240 & 270 & 270 & 0.74 & 0.89 \\
\hline Sand & $\mathrm{M}^{3}$ & 710 & 100 & 160 & 220 & 220 & 0.45 & 0.73 \\
\hline Red bricks & 1000 & 269 & 600 & 950 & 750 & 1000 & 0.80 & 0.95 \\
\hline
\end{tabular}

Also, it is noted that most contractors and consultants do not know how to prepare price adjustment claims.

When comparing the prices with validations prices, the prices of local materials approximately equal but there is a little difference in the prices due to the location of the projects in Khartoum, and the material like reinforcement there is difference maybe its highest price of material or it depends on dollar rate changings as illustrated in Fig. 3.

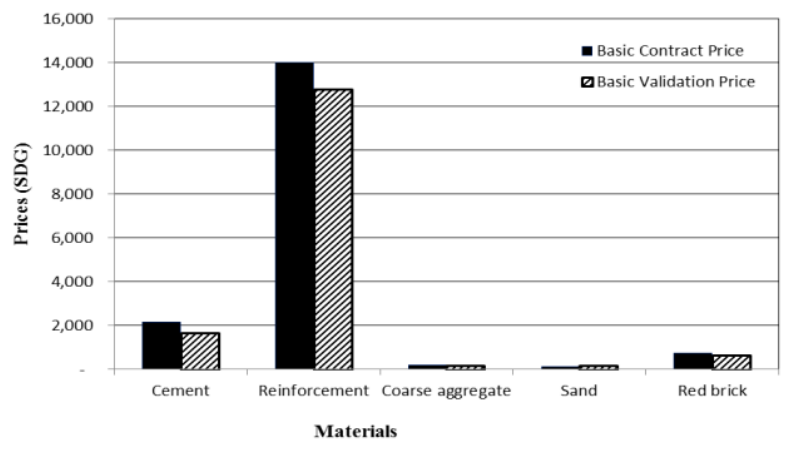

Fig. 3: Comparing between BCP \& BVP in Khartoum
When comparing prices of East and West of Sudan with Khartoum projects, as illustrated in Fig 4, 5, 6\&7, there are some differences in some materials due to many reasons such as transportations from production location and the states (distance from Khartoum to Qadarif $417 \mathrm{~km}$ and Khartoum - Zalingei about 1,439 km). On the other hand, some materials are locally available like sand in the West of Sudan makes the prices lower. It is noteworthy that for the project in the West, the prices of the contractor for cement and reinforcement are lower than prices in Khartoum. This is unrealistic, and the contractor may lower his bid prices deliberately to gain higher price adjustment as in Figure 5, it is important to watch out for such irregularity and request from contractors to provide evidence of their basic bid prices, as well as current claim prices. 
TABLE III: CLAIMANT PROJECTS AFFECTED BY THE LEGISLATION

\begin{tabular}{l|r|r|r}
\hline \multicolumn{1}{|c|}{ legislation } & & & \\
\hline $\mathrm{X} 1$ & & & \\
\hline $\mathrm{X} 2$ & & & \\
\hline $\mathrm{X} 3$ & & & Leg. Nov-17 \\
\hline $\mathrm{X} 4$ & & 1.46 & 2.54 \\
\hline \hline
\end{tabular}

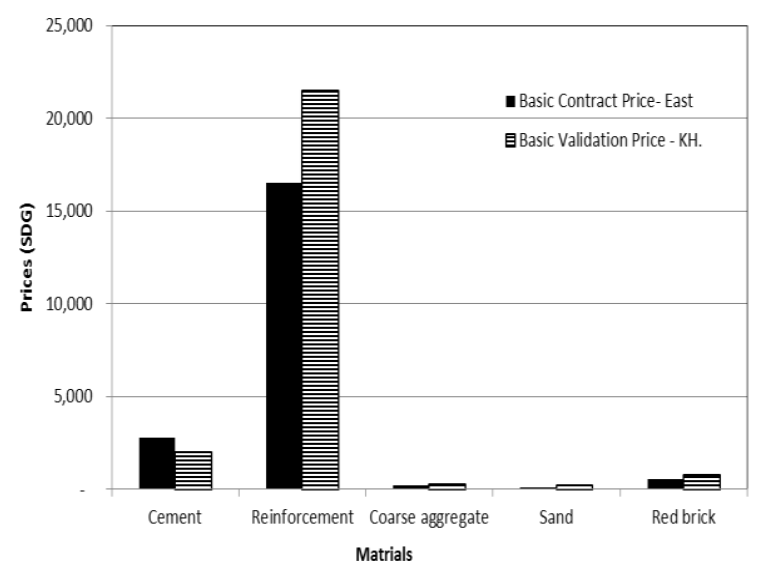

Fig.4: Comparing between BCP \& BVP of Eastern of Sudan and Khartoum.

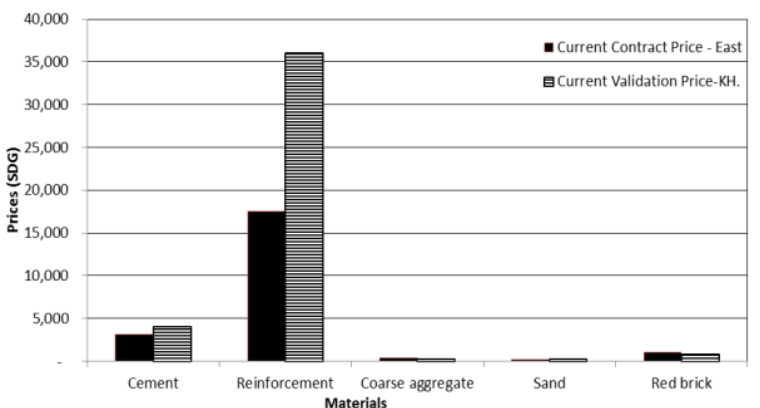

Fig.5: Comparing between CCP \& CVP of Eastern of Sudan and Khartoum.

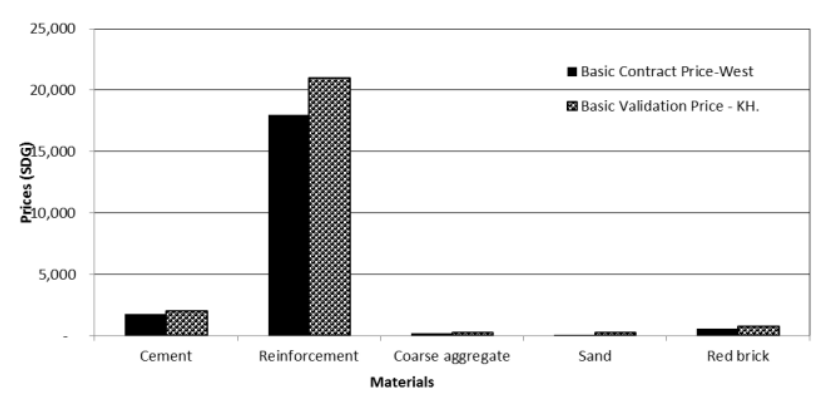

Fig.6: Comparing between BCP \& BVP of Western of Sudan and Khartoum.

Some material like reinforcement follows the dollar rates as in Fig. 8 because it depends on the importing the raw material from aboard, and some materials do not follow dollar rates because it depends on local material.

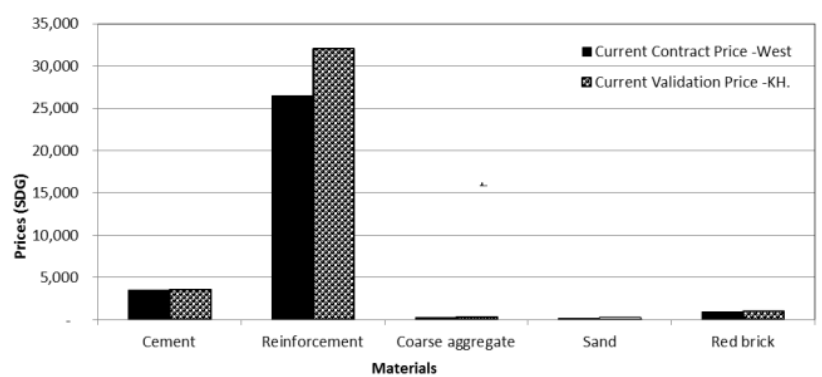

Fig. 7: Comparing between CCP \& CVP of Western of Sudan and Khartoum.

\section{CONCLUSIONS AND RECOMMENDATIONS}

1- The Mini Technical Committee (MTC) has decided to use the formula to adjust prices for projects, and following approval procedure and proposal to pay the differences in prices.

2- From the minutes of the MTC meetings, it is observed that most contractors and consultants do not know how to prepare price adjustment claims.

3- Comparing some data submitted by some contractors for three projects in east Sudan, West Sudan and Khartoum that have been approved by consultants with prices of materials obtained from an independent third party in Khartoum.

4- The validation of the information revealed that some contractors use incorrect prices, and this misleading in effort to maximize price adjustment. Therefore, the government or the responsible authorities must set daily prices and indicators for the prices of all construction material and labour costs.

5- Reviewing prices of the three projects revealed that local materials like brick and aggregates are not affected by USD dollar rate, on the contrary to the cement and steel reinforcement that are affected by inflation rate of the dollar.

\section{REFERENCES}


[2] 2012 1_badell Date uploadedon Jan 31,

“https://www.scribd.com/document/79917882/Chapter-10-

Escalation," pp. 1-6.

[3] M. Allingham, "Price Adjustment," Resource Allocation and Economic Policy, no. June. pp. 5-13, 1976, doi:

10.1007/978-1-349-02673-9_1.

[4] K. Vamsidhar, D. A. Eshwarswaroop, K.

Ayyappapreamkrishna, and R. Gopinath, "Study and Rate Analysis of Escalation in Construction industry," IOSR J.

Mech. Civ. Eng., vol. 11, no. 2, pp. 14-25, 2014, doi: 10.9790/1684-11251425.

[5] P. Morris and W. F. Willson, "Measuring and managing cost escalation," AACE Int. Trans., vol. 2006, pp. 1-7, 2006.

[6] F. International and C. Engineers, "Conditions of Contract for Construction HARMONISED EDITION," no. June, 2010.

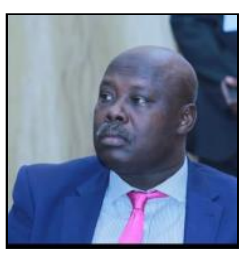

Dr Yousif Hummaida Ahmed (PhD, DIC, $\mathrm{BSc}), \mathrm{phD}$ in Engineering from emperial college /university of London (1996) Awarded Dr. Shawki Saad Scholarship. Specialization concrete durability \&hazardous waste management technologies former Head of Civil engineering Department, faculty of engineering, University of Khartoum, Sudan. Currently Chairman of the governmental Council for Registering and Classifying Engineering Works Contractors.

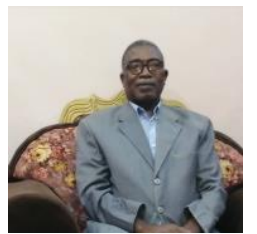

Mr Nasrddin Khalil Sharafeldin (BSc), Architecture Engineering Department, faculty of engineering, University of Khartoum, Sudan. (April 1984 - May 1989) Architectural design and bill of quantities supervision at SEMAC International Consultant, (May 1989 Aug.2002) head of Dep. Of Estimator of projects planning and head of Dep. Of projects execution at Real Estate Development Co.TD, Currently Architectural designs, building supervision and Assets validation.

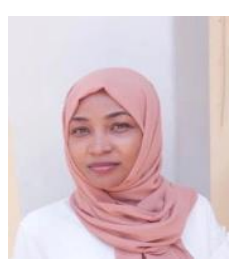

Ms. Eman Norallah Mohamed Taber (BSc,MSc). She received a bachelor's degree in civil engineering from Sudan University of Science and Technology, and master's degrees in structural engineering from University of Khartoum in Sudan. Currently works at Kenana Engineering and Technical Service as a Civil

Engineer Coordinator. 